\title{
DORĘCZENIA ZAGRANICZNE W POSTĘPOWANIU ADMINISTRACYJNYM I SĄDOWO-ADMINISTRACYJNYM - PROBLEMY PRAKTYCZNE
}

\begin{abstract}
Streszczenie. Problematyka doręczania pism w postępowaniu administracyjnym i sądowo-administracyjnym dokonywanych poza granicę Rzeczypospolitej Polskiej, w kontekście prawa Unii Europejskiej, a w szczególności orzecznictwa Trybunału Sprawiedliwości, wyznaczających standardy doręczania pism, nabiera coraz większego znaczenia. Źródłem istotnych problemów praktycznych jest brak unormowań dotyczących doręczania pism w ogólnym postępowaniu administracyjnym zarówno między państwami UE (z wyjątkiem spraw podatkowych i celnych, w odniesieniu do których obowiązują stosowne regulacje), jak i do państw niebędących członkami UE. Poza klasycznym sposobem doręczenia za pośrednictwem operatora pocztowego, które niestety nie zawsze jest skuteczne, zastosowanie znajdują posiłkowo stosowane inne sposoby doręczeń. Stwierdzić jednak należy, iż brakuje regulacji jednolicie normujących sposoby doręczania w różnych rodzajach postępowań, co prowadzi do nieuzasadnionego zróżnicowania standardów w zakresie doręczeń w zależności od przedmiotu postępowania.
\end{abstract}

Słowa kluczowe: doręczanie pism, doręczenia zagraniczne, obrót zagraniczny, pełnomocnik do doręczeń, prawo konsularne.

\section{WPROWADZENIE}

Doręczenia pism w postępowaniu administracyjnym i sądowo-administracyjnym klasyfikuje się jako prawną formę działań administracji, to jest czynność materialno-techniczną, która poprzez czynność faktyczną wywołuje określony skutek prawny. Podkreślić przy tym należy, iż pod pojęciem „pisma” rozumieć należy zarówno pisma wszczynające postępowanie w sprawie (wnioski wszczynające postępowanie, zawiadomienia organu o wszczęciu postępowania z urzędu, rozstrzygnięcia dokonane przez organ bądź sąd administracyjny, odwołania, skargi, skargi kasacyjne, zażalenia, wezwania itp. (szerzej zob. Łaszczyca, Matan 1998; Szuma 2014, 29-33; Cisowska-Sakrajda 2010, 34-36). Pomimo że czynność doręczenia nie stanowi żadnej z kategorii czynności (form działania) nakierowanych bezpośrednio na załatwienie czy też rozstrzygnięcie danej sprawy

${ }^{*}$ Uniwersytet Łódzki, Katedra Prawa Administracyjnego i Nauki Administracji, Zakład Prawa Administracyjnego, rlewicka@wpia.uni.lodz.pl. 
administracyjnej, to jednak doniosłość tej czynności powoduje, iż wszelkie przepisy prawne regulujące sposoby, terminy czy też podmioty dokonujące doręczenia, jak i uprawnione do odbioru przesyłek, traktowane są jako przepisy ius cogens, a zatem bezwzględnie wiążące, o charakterze obligatoryjnym, który wyłącza swobodną dyspozycję stron w zakresie sposobu doręczenia pism. Związane jest to z przyjętą w prawie polskim zasadą oficjalności doręczeńn ${ }^{1}$, z której wynika obligatoryjne doręczanie „pism” przez organ lub sąd prowadzący postępowanie, czyli doręczenia dokonywane $\mathrm{z}$ urzędu².

Prawidłowe doręczenie pisma stanowi wyraz realizacji przez organ lub sąd prowadzący postępowanie zasad ogólnych postępowania administracyjnego, w tym zawartej w art. 10 k.p.a. zasady czynnego udziału w każdym stadium postępowania oraz zasady informowania stron (art. 9 k.p.a.), natomiast w postępowaniu sądowo-administracyjnym wypełnia konstytucyjną zasadę jawności postępowania, stanowiąc tym samym gwarancję umocowanego konstytucyjnie prawa do sądu. Jedną z podstawowych funkcji doręczenia (w odpowiednim czasie) jest umożliwienie adresatowi zrozumienia przedmiotu i przyczyny wydania doręczonego aktu oraz umożliwienie wykonania jego praw ${ }^{3}$.

Skuteczne doręczenie danego pisma zainteresowanemu jest podstawowym warunkiem prawidłowego przebiegu postępowania, zaś obowiązek umożliwienia stronie zapoznania się z treścią pism, jak i otrzymywanie zawiadomień pozwala na, odpowiednie do etapu danego postępowania, reagowanie na podejmowane przez organ lub sąd, a czasem również inne strony, działania w toku tego postępowania, a na dalszym etapie także kwestionowanie zapadłych w sprawie rozstrzygnięć $\mathrm{w}$ drodze szeroko rozumianego ich zaskarżenia. $Z$ uwagi przy tym na określoną przez ustawodawcę terminowość podejmowania danych czynności w postępowaniu (która dotyczy nie tylko organów, ale także stron) istotne znaczenie ma ustalenie daty doręczenia pisma dla określenia rozpoczęcia i zakończenia biegu danego terminu. Tematyka doręczeń była szeroko podejmowana w literaturze prawa i postępowania administracyjnego, stąd nie ma potrzeby szerszego

${ }^{1}$ Np. postanowienie Sądu Najwyższego z 5 października 1994 r., III ARN 54/94, Lex.

${ }^{2}$ Aktualnie, to jest od 15 sierpnia 2015 r., p.p.s.a. w art. $66 \S 1$ przewiduje obligatoryjne doręczanie w toku sprawy pism przez adwokatów, radców prawnych, doradców podatkowych i rzeczników patentowych sobie nawzajem za potwierdzeniem odbioru lub przesyłką poleconą, z wyjątkiem skargi, skargi kasacyjnej, zażalenia, sprzeciwu, skargi o wznowienie postępowania i skargi o stwierdzenie niezgodności z prawem prawomocnego orzeczenia (wcześniej było to fakultatywne). Rozwiązanie takie funkcjonuje także na gruncie ustawy - Kodeks postępowania cywilnego (art. 132) już od 19 kwietnia 2010 r. Rozwiązanie to stanowi swego rodzaju wyjątek od zasady oficjalności doręczania, choć podkreślić należy, iż w ten sposób doręczane są jedynie pisma stron czy też uczestników postępowania zawierające ich wnioski bądź oświadczenia, z wyjątkiem pism wszczynających postępowanie oraz środków zaskarżenia).

${ }^{3}$ Wyrok TS z dnia 8 maja 2008 r. w sprawie C-14/07 Weiss und Partner (Dz. U. UE. L.2000.160.37), przywołany w uzasadnieniu wyroku TS z dnia 14 stycznia 2010 r. w sprawie C-233/08 Kyrian (Dz. U. UE. L.1976.73.18). 
omawiania znaczenia tej czynności. Jednocześnie, pomimo stosunkowej prostoty czynności doręczenia, nadal występuje szereg istotnych wątpliwości powstających na gruncie możliwych do zaistnienia stanów faktycznych. Niniejsze opracowanie, z uwagi na jego ograniczone ramy, poświęcone zostanie wyłącznie problematyce dokonywania tzw. doręczeń zagranicznych na tle ostatnich zmian legislacyjnych, bez uwzględniania doręczeń za pomocą środków komunikacji elektronicznej4.

W pierwszej kolejności wskazać należy, iż ani k.p.a, ani p.p.s.a. nie zawierają szczególnych uregulowań dotyczących doręczenia dokonywanego dla strony mającej miejsce zamieszkania, pobytu bądź siedzibę za granicą. Oznaczałoby to zatem, iż do doręczeń w tych postępowaniach co do zasady zastosowanie znajdują przepisy regulujące doręczenia krajowe. Konkluzja taka jednakże wydaje się nie do końca prawidłowa, jeśli weźmie się pod uwagę szereg uwarunkowań i ograniczeń $\mathrm{w}$ stosowaniu prawa polskiego przy podejmowaniu czynności doręczenia w innym państwie. Podkreślenia bowiem wymaga, iż na gruncie procedur prawa administracyjnego zarówno krajowego, jak i międzynarodowego brakuje kompleksowej regulacji dokonywania takich doręczeń. Międzynarodowe umowy wielostronne bądź akty prawne regulują bowiem zasadniczo problematykę związaną ze sprawami cywilnymi (szeroko rozumianymi) ${ }^{5}$, handlowymi bądź karnymi.

W ramach Unii Europejskiej największe znaczenie w zakresie doręczania posiada rozporządzenie nr 1393/2007 Parlamentu Europejskiego i Rady z dnia 13 listopada 2007 r. dotyczące doręczania w państwach członkowskich dokumentów sądowych i pozasądowych w sprawach cywilnych i handlowych (doręczanie dokumentów) oraz uchylające rozporządzenie Rady (WE) nr 1348/2000. Rozporządzenie to nie zawiera przy tym definicji ani katalogu „sprawy cywilnej”, jednak z jego art. 1 wprost wynika, że nie dotyczy ono spraw podatkowych, celnych, administracyjnych ani spraw dotyczących odpowiedzialności państwa za działania lub zaniechania w wykonywaniu władzy publicznej (acta iure imperia). W konsekwencji stwierdzić należy, iż rozporządzenie nr 1393/2007 nie znajduje zastosowania w postępowaniu administracyjnym i sądowo-administracyjnym, choć można przyjać, że w sytuacji gdy organ władzy publicznej nie wykonuje władztwa publicznego, załatwiana przez niego sprawa może mieć walor „sprawy cywilnej”. Doręczenia pism dla podmiotów spoza państw członkowskich Unii Europejskiej dokonywane są natomiast w oparciu o umowę wielostronną sporządzoną w Hadze 15 listopada 1965 r. - Konwencję o doręczaniu za granicą dokumentów sądowych i pozasądowych w sprawach cywilnych lub handlowych,

\footnotetext{
${ }^{4} \mathrm{~W}$ rozumieniu wynikającym z definicji zawartej w art. 2 pkt 5 ustawy z dnia 18 lipca $2002 \mathrm{r}$. o świadczeniu usług drogą elektroniczną, zgodnie z którym środki komunikacji elektronicznej to rozwiązania techniczne, $\mathrm{w}$ tym urządzenia teleinformatyczne i współpracujące $\mathrm{z}$ nimi narzędzia programowe, umożliwiające indywidualne porozumiewanie się na odległość przy wykorzystaniu transmisji danych między systemami teleinformatycznymi, a w szczególności pocztę elektroniczną.

${ }^{5}$ Przeglądu orzecznictwa TS oraz ETPCz obejmującego rozumienie pojęcia „sprawa cywilna” dokonał M. Piłaszewicz (Piłaszewicz 2014, 38-43).
} 
jednak, jak wskazuje sam tytuł tego aktu, ma ona również zastosowanie jedynie do spraw cywilnych i handlowych ${ }^{6}$.

Rzeczpospolita Polska zawarła również szereg umów dwustronnych dotyczących pomocy prawnej, jednak ich znakomita większość również sprowadza się do objęcia zakresem ich stosowania spraw cywilnych i handlowych, rodzinnych, pracowniczych bądź karnych. Nadal jedynie w umowie zawartej między Rzeczpospolitą Polską a Rumunią przewidziane jest objęcie zakresem przedmiotowym tej umowy także spraw sądowo-administracyjnych (art. 1). Biorąc zatem pod uwagę obowiązujące bądź wiążące Polskę akty lub umowy międzynarodowe, stwierdzić należy, iż nie regulują one zasad i trybu doręczania pism w postępowaniu administracyjnym i sądowo-administracyjnym.

\section{DORĘCZENIA ZA POŚREDNICTWEM OPERATORA POCZTOWEGO}

Na gruncie obowiązujących przepisów k.p.a. i p.p.s.a. doręczenia dokonywane są przede wszystkim za pośrednictwem operatora pocztowego. Zgodnie z treścią art. 39 k.p.a., organ administracji publicznej doręcza pisma za pokwitowaniem przez operatora pocztowego ${ }^{7} \mathrm{~W}$ rozumieniu ustawy z dnia 23 listopada $2012 \mathrm{r}$. - Prawo pocztowe, przez swoich pracowników lub przez inne upoważnione osoby lub organy. Tożsamy sposób doręczenia przewiduje art. $65 \S 1$ p.p.s.a., z dodatkowym zastrzeżeniem, iż do doręczania pism w postępowaniu sądowym przez operatora pocztowego stosuje się tryb doręczania pism sądowych w postępowaniu cywilnym, o ile przepisy p.p.s.a. nie stanowią inaczej. W art. $299 \S 1$ p.p.s.a. ustawodawca przyjął ponadto, iż w przypadku adresata niemającego miejsca zamieszkania, miejsca zwykłego pobytu albo siedziby w państwie członkowskim Unii Europejskiej, Konfederacji Szwajcarskiej lub państwie członkowskim Europejskiego Porozumienia o Wolnym Handlu (EFTA) - stronie umowy o Europejskim

${ }^{6} \mathrm{~W}$ literaturze przyjmuje się natomiast zastosowanie do spraw sądowo-administracyjnych Konwencji z 25 października 1980 r. o ułatwieniu dostępu do wymiaru sprawiedliwości w stosunkach międzynarodowych (Ciszewski 2006, 20-21), jednakże Konwencja ta dotyczy przyznawania prawa pomocy.

${ }^{7} \mathrm{Na}$ marginesie tylko (bez większego związku z powyższymi rozważaniami i jako przykład braku konsekwencji ustawodawcy przy nowelizowaniu k.p.a. i p.p.s.a.) można przy tym wskazać, że zarówno p.p.s.a., jak i Kodeks postępowania cywilnego zrównują (odpowiednio w art. $83 \S 3$ p.p.s.a. i art. $165 \S 2$ k.p.c.) skutki oddania pisma (istotne z punktu widzenia zachowania termi$\mathrm{nu}) \mathrm{w}$ polskiej placówce pocztowej operatora wyznaczonego, $\mathrm{z}$ oddaniem w placówce pocztowej operatora świadczącego pocztowe usługi powszechne w innym państwie członkowskim Unii Europejskiej, Konfederacji Szwajcarskiej lub państwie członkowskim Europejskiego Porozumienia o Wolnym Handlu (EFTA) - stronie umowy o Europejskim Obszarze Gospodarczym, uznając je za równoznaczne z wniesieniem pisma do sądu. Regulacji takiej nie zawiera natomiast k.p.a., który dla wywołania tego skutku wymaga (poza innymi sposobami wnoszenia pism) nadania go w polskiej placówce pocztowej operatora wyznaczonego. 
Obszarze Gospodarczym sąd doręcza pisma pocztą przesyłką poleconą za potwierdzeniem odbioru lub równoważną przesyłką.

Doręczenia za pośrednictwem operatora pocztowego powinny być zatem standardem stosowanym także przy doręczeniach zagranicznych (podobnie Chróścielewski 2016, 18). Zgodnie z art. 4 Prawa pocztowego do świadczenia usług pocztowych $\mathrm{w}$ obrocie zagranicznym stosuje się przepisy ustawy, jeżeli międzynarodowe przepisy nie stanowią inaczej ${ }^{8}$. Organ lub sąd powinny zatem co do zasady w pierwszej kolejności skorzystać z tej drogi doręczenia, zgodnie z zawarta z operatorem pocztowym umowa, natomiast operator przekazuje przesyłkę operatorowi pocztowemu państwa, w którym znajduje się siedziba, miejsce zamieszkania lub miejsce pobytu zwykłego adresata, i ten operator dokonuje faktycznego doręczenia. Ocena skuteczności takiego doręczenia powinna co do zasady odbywać się według prawa państwa obcego, o czym świadczy chociażby zawarte prawie w każdej umowie międzynarodowej dwustronnej, której stroną jest Polska, zastrzeżenie stosowania przez organ wezwany przepisów prawnych swego państwa. Doręczenie przez operatora pocztowego innego państwa należy uznać za zrównane $\mathrm{z}$ doręczeniem dokonanym przez polskiego operatora pocztowego. Doręczenie za pośrednictwem operatora pocztowego wydawałoby się zatem najbardziej celowe i szybkie. Powstają jednak w praktyce dwa istotne problemy, których wyeliminowanie przy doręczeniach pocztowych de facto nie jest możliwe.

\subsection{Zwrotne poświadczenie odbioru}

Po pierwsze, jak wynika z regulacji zarówno art. 39 k.p.a., jak i art. $65 \S 1$ p.p.s.a., doręczenia takiego dokonuje się ,za pokwitowaniem odbioru”. Znaczenie takiego dokumentu jest o tyle istotne, że z jednej strony świadczy o rzeczywistym dotarciu przesyłki do adresata, a więc również umożliwieniu mu zapoznania się z jej treścią (abstrahując w tym miejscu od fikcji doręczenia zastępczego), $\mathrm{z}$ drugiej zaś zawiera datę dokonania odbioru stanowiąca, w odniesieniu do pism wymagających podjęcia przez adresata czynności w określonym terminie, datę początkową biegu tego terminu. Zgodnie z przywołanym już artykułem 137 ust. 1 Regulaminu Poczty Listowej Światowego Związku Pocztowego (Berno 2005),

${ }^{8}$ Pojęcie „międzynarodowe przepisy pocztowe” zostało zdefiniowane w art. 3 pkt 7 Prawa pocztowego i oznacza wiążące Rzeczpospolitą Polską umowy międzynarodowe dotyczące świadczenia usług pocztowych oraz wiążące regulaminy Światowego Związku Pocztowego. W szczególności dotyczy to Regulaminu Poczty Listowej Światowego Związku Pocztowego sporządzonego w Bernie 28 stycznia 2005 r., który m.in. przewiduje możliwość dokonywania doręczeń za potwierdzeniem odbioru bądź do rąk własnych (art. 137 i 138), a także Regulaminu Generalnego Światowego Związku Pocztowego wraz z załącznikiem - Regulaminem wewnętrznym Kongresów, Światowej Konwencji Pocztowej wraz z Protokołem końcowym, Porozumienie dotyczące pocztowych usług płatniczych, sporządzonym w Dausze 11 października 2012 r. 
w obrocie między administracjami, które świadczą usługę potwierdzeń odbioru dla swych klientów, nadawca przesyłki poleconej, przesyłki z poświadczonym doręczeniem lub przesyłki z zadeklarowaną wartością może zażądać potwierdzenia odbioru w chwili nadania. Potwierdzenie odbioru zwraca się nadawcy najszybszą drogą (lotniczą lub lądowo-morską). Z kolei zgodnie z art. 137 ust. 2 pkt 3.1 tego Regulaminu - potwierdzenie odbioru powinno zostać podpisane w pierwszej kolejności przez adresata, a gdy to nie jest możliwe, przez inną osobę do tego upoważnioną na mocy przepisów kraju przeznaczenia. Jeśli przepisy na to pozwalają, to, z wyjątkiem przesyłek doręczanych do rąk własnych adresata, potwierdzenie odbioru może zostać podpisane przez pracownika urzędu przeznaczenia. Takie zwrotne potwierdzenie odbioru w praktyce jest najbardziej zawodnym elementem tego sposobu doręczania. Często bowiem zdarza się, że po wysłaniu przesyłki doręczanej za granicę, takie zwrotne poświadczenie odbioru jest zwracane bez podpisu odbiorcy (tzn. bez wypełnienia stosownych rubryk formularza), co uniemożliwia uznanie, że doszło do skutecznego doręczenia. Pojawia się także problem nieczytelnego pokwitowania odbioru, uniemożliwiającego identyfikację. Jednakże, z uwagi na dokonywanie takiego doręczenia przez operatora świadczącego usługi pocztowe w oparciu o stosowne regulacje prawa wewnętrznego danego kraju oraz przepisy pocztowe międzynarodowe, można uznać go za mniej istotny, przyjmując prawidłowe wykonanie doręczenia do rąk adresata bądź osoby uprawnionej do odbioru. W przypadku natomiast braku podpisania (pokwitowania) potwierdzenia odbioru, zakładając faktyczne doręczenie przesyłki, można wyróżnić dwie sytuacje: adresat zamierza podjąć działanie stosownie do treści doręczonego pisma (np. wnieść odwołanie czy skargę) albo też nie zamierza podejmować żadnych czynności. W pierwszej z wyróżnionych sytuacji, o ile pismo było „terminowe”, można poczekać do upływu tego terminu i jeśli zostanie przez adresata dokonana czynność - uznać, iż doręczenie było skuteczne. W drugiej natomiast sytuacji, po bezskutecznym upływie terminu do podjęcia czynności, należy dokonać ponownego doręczenia. Zdarzają się także sytuacje, w których nie następuje zwrot przesyłki do nadawcy ani potwierdzenia odbioru. Przykładowo, sytuacja taka jest standardowa w przypadku doręczeń drogą pocztową do Wielkiej Brytanii. Angielski operator pocztowy - Royal Mail - nie przewiduje w ogóle zwrotnych potwierdzeń odbioru przesyłek zagranicznych. Skutkuje to brakiem przekazania zwrotnego potwierdzenia odbioru, a co za tym idzie brakiem możliwości uznania, że doszło do skutecznego doręczenia ${ }^{9}$. Doręczenie przesyłek za pośrednictwem operatora pocztowego do adresata mającego siedzibę lub miejsce zamieszkania bądź pobytu zwykłego w Wielkiej Brytanii jest w związku z tym nie do końca racjonalne i może prowadzić do przedłużenia postępowania o czas oczekiwania na zwrot potwierdzenia odbioru. Oczywiście może także

${ }^{9}$ Autorka powyższe przykłady przedstawia z własnego doświadczenia zawodowego - sędziego Sądu Okręgowego Sądu Gospodarczego w Łodzi. 
wystąpić sytuacja, gdy pomimo braku pokwitowania odbioru, adresat podejmie działanie, które świadczy o skutecznym doręczeniu. Tutaj jednak także pojawia się problem związany z ustaleniem zachowania przez niego terminu do dokonania danej czynności (o ile ma ona charakter „terminowy”). Jeśli potwierdzenie odbioru zostanie zwrócone nawet bez podpisu odbiorcy, to zazwyczaj znajduje się na nim stempel operatora pocztowego $\mathrm{z}$ datą zwrotu do nadawcy, zaś taki zwrot następuje najczęściej tego samego bądź następnego dnia po doręczeniu, a zatem w oparciu o datę wskazaną na stemplu można ustalić najpóźniejszą możliwą datę doręczenia i na tej podstawie ustalić zachowanie terminu przez adresata. Nie można także pominąć $\mathrm{w}$ omówieniu tych problemów możliwości wystapienia $\mathrm{z}$ reklamacją do operatora polskiego (jako bezpośredniego, z którym zawarta została umowa o świadczenie usług pocztowych). W przypadku zatem braku przekazania zwrotnego potwierdzenia odbioru, na skutek złożonej reklamacji, operator państwa obcego najczęściej przekazuje operatorowi polskiemu odpowiedź na reklamację, w której niekiedy wskazuje, że doręczenie nastąpiło w danym dniu. O ile przy tym adresat podjął działanie, to w zakresie ustalenia samej daty doręczenia, informacje zawarte $\mathrm{w}$ odpowiedzi na reklamację mogą posłużyć do ustalenia zachowania terminu, jednak w przypadku braku podjęcia działania przez adresata, w mojej ocenie sama taka odpowiedź na reklamację nie może stanowić podstawy do uznania, że doszło do skutecznego doręczenia przesyłki.

\subsection{Doręczenia zastępcze}

Drugi istotny problem praktyczny przy dokonywaniu doręczeń zagranicznych za pośrednictwem operatora pocztowego stanowi kwestia tzw. doręczenia zastępczego, przewidzianego w art. 44 k.p.a. i 73 p.p.s.a., skutkującego przyjęciem prawnej fikcji doręczenia. W sytuacji zatem doręczenia zagranicznego, w wyniku którego dochodzi do zwrotu przez operatora pocztowego niedoręczonej przesyłki, przy czym w zależności od państwa, w którym miało nastąpić doręczenie, na kopercie mogą znajdować się adnotacje i stemple pocztowe sugerujące odpowiednik przewidzianego $\mathrm{w}$ prawie polskim awizowania przesyłki. Powstaje w tym momencie pytanie, czy dokonanie awizowania takiej przesyłki przez operatora pocztowego państwa odbiorcy stanowi odpowiednik polskiej regulacji, pozwalający na przyjęcie fikcji doręczenia. W mojej ocenie udzielenie odpowiedzi pozytywnej wzbudza wątpliwości. Co prawda można zgodzić się z tezą zrównującą doręczenie dokonane przez operatora zagranicznego z doręczeniem dokonanym przez operatora krajowego, uznając je w świetle zarówno regulacji k.p.a., jak i p.p.s.a. za równoważne (działania operatora zagranicznego stanowią bowiem kontynuację działań operatora krajowego). Aby można było przyjąć jednak skuteczność takiego doręczenia zastępczego, należałoby co najmniej ustalić, czy sposób dokonania awizacji przesyłki odpowiada określonym w prawie polskim regułom co do czasu pozostawienia przesyłki z możliwością jej odbioru, 
sposobu dokonania powiadomienia o miejscu, terminie i samej możliwości odbioru takiej przesyłki, a ponadto ustalić także, czy prawo obce przewiduje taki sposób doręczenia oraz czy dokonane przez operatora zagranicznego awizowanie przesyłki spełnia wymogi stawiane także przez regulację prawa obcego. W tym celu niezbędne byłoby sięgnięcie do przepisów prawa obcego. O ile przy tym sąd administracyjny, w oparciu o treść art. 300 p.p.s.a., który przewiduje stosowanie do postępowania $\mathrm{w}$ zakresie obrotu zagranicznego $\mathrm{w}$ sprawach nieuregulowanych w p.p.s.a. odpowiednio przepisów o ustroju sądów powszechnych oraz przepisów Kodeksu postępowania cywilnego dotyczących międzynarodowego postępowania cywilnego, miałby możliwość zwrócenia się w oparciu o art. 1143 k.p.c. do Ministra Sprawiedliwości o udzielenie tekstu prawa obcego oraz o wyjaśnienie obcej praktyki sądowej (podobnie Ciszewski 2006, 40), o tyle przepisy k.p.a. takiego odesłania nie przewidują. Mając zatem na względzie zarówno czasochłonność tych czynności, jak i ryzyko błędu w zakresie ustalenia skuteczności takiego doręczenia (przy chociażby jednoczesnym braku możliwości zweryfikowania prawidłowości adresu, pod którym doszło do doręczenia zastępczego), wydaje się niezasadne stosowanie fikcji doręczenia w odniesieniu do doręczeń zagranicznych.

\section{INNE SPOSOBY DORĘCZANIA DOKUMENTÓW}

W sytuacji, gdy doręczenie za pośrednictwem operatora pocztowego okazuje się nieskuteczne (m.in. z opisanych wyżej przyczyn) bądź, w ocenie organu lub sądu, z innych względów niecelowe, istnieje także możliwość posłużenia się innymi sposobami doręczenia (pomijając oczywiście jako niecelowe w takich przypadkach doręczenia dokonywane np. przez pracownika bądź przez obwieszczenie).

\subsection{Doręczenia za pośrednictwem konsula}

Doręczenie pism za pośrednictwem konsula przewiduje art. 26 ust. 1 ustawy z 25 czerwca 2015 r. - Prawo konsularne, zgodnie z którym, na wniosek organu administracji publicznej w Rzeczpospolitej Polskiej, sądu lub prokuratora konsul: 1) doręcza pisma i inne dokumenty; 2) przesłuchuje strony, uczestników postępowania, świadków i podejrzanych; 3) przekazuje wnioski o udzielenie pomocy prawnej sądom i innym organom państwa przyjmującego. Rozróżnienia wymaga przy tym dokonywanie doręczeń dla adresata będącego obywatelem polskim i pośredniczenie w doręczaniu pism osobom nieposiadającym polskiego obywatelstwa. W odniesieniu do obywatela polskiego konsul wykonuje doręczenie bądź przesłuchanie, stosując odpowiednio właściwe przepisy prawa polskiego, o ile adresat zgadza się dobrowolnie przyjąć pismo lub inny dokument albo złożyć zeznanie lub wyjaśnienie. Przyjmuje się przy tym, że doręczenia konsul może dokonać bądź do 
rąk własnych adresata w konsulacie, bądź przez upoważnionego pracownika za potwierdzeniem odbioru. Przewidziany w art. 26 ust. 2 Prawa konsularnego wymóg dobrowolności oznacza, że skuteczność doręczenia pism przesyłanych pocztą przez polskiego konsula istnieje tylko wówczas, gdy odbiorca osobiście odbierze przesłane do niego pismo bądź ustanowi pełnomocnika do odbioru pisma (Wach 2015) ${ }^{10}$.

Doręczenia natomiast pism, których odbiorcami nie są obywatele polscy, konsul nie może dokonywać samodzielnie. Jak już wyżej podkreślano, podstawę prawną do doręczania pism sądowych $\mathrm{w}$ stosunkach Polski z zagranicą stanowią umowy międzynarodowe, przepisy wewnętrzne, umowy dwustronne, natomiast z państwami, z którymi Polska nie uregulowała tych spraw na podstawie umów, pomoc ta odbywa się na zasadzie zwyczajowego świadczenia sobie wzajemnych usług w tym zakresie i z reguły nie wywołuje przeszkód do udzielenia takiej pomocy prawnej (Wach 2015). Aktem podstawowym przewidującym dopuszczalność dokonywania przez konsulów doręczeń (wniosków o udzielenie pomocy prawnej) dla podmiotów niebędących obywatelami państwa wysyłającego jest Konwencja o stosunkach konsularnych sporządzona w Wiedniu 24 kwietnia 1963 r., która w art. 5 zawiera katalog funkcji konsularnych, a wśród nich - w art. 5 pkt j) - wymienia przesyłanie sądowych i pozasądowych dokumentów oraz wykonywanie rekwizycji sądowych zgodnie z obowiązującymi umowami międzynarodowymi lub, w braku takich umów, w sposób zgodny z ustawami i innymi przepisami państwa przyjmującego. Za utrwaloną w praktyce uznaje się dopuszczalność upoważnienia konsula, na podstawie umów międzynarodowych zawartych pomiędzy państwem wysyłającym i przyjmującym, ale także w oparciu o przepisy albo praktykę państwa pobytu, do doręczania pism i dokumentów także obywatelom państwa przyjmującego (państwa pobytu). Jednakże w braku takiego upoważnienia, konsul powinien przekazać niezwłocznie właściwym organom miejscowym pisma i dokumenty przekazane mu celem doręczenia adresatowi (niebędącemu obywatelem Polski), przy zastosowaniu prawa państwa przyjmującego. Doręczenia za pośrednictwem konsula mogą być zatem wykorzystane zarówno w postępowaniu administracyjnym, jak i sądowo-administracyjnym.

\subsection{Doręczenia za pośrednictwem organu doręczającego bądź sądu}

W postępowaniu sądowo-administracyjnym dodatkowo istnieje możliwość dokonywania doręczeń zagranicznych w oparciu o przepisy rozporządzenia Ministra Sprawiedliwości z dnia 28 stycznia 2002 r. w sprawie szczegółowych czynności sądów w sprawach z zakresu międzynarodowego postępowania cywilnego

${ }^{10} \mathrm{Z}$ uwagi na tożsamość regulacji zawartej w komentowanym art. 18 nieobowiązującej już ustawy z art. 26 nowej ustawy Prawo konsularne, uwagi te zachowują w pełni aktualność. 
oraz karnego w stosunkach międzynarodowych ${ }^{11}$, na podstawie art. 300 p.p.s.a., przewidującego zastosowanie, w sprawach nieuregulowanych w p.p.s.a., do postępowania w zakresie obrotu zagranicznego odpowiednio przepisów o ustroju sądów powszechnych oraz przepisów Kodeksu postępowania cywilnego dotyczących międzynarodowego postępowania cywilnego. Zgodnie z § 18 ust. 1 rozporządzenia, pisma podlegające wysłaniu za granicę prezesi sądów okręgowych i prezesi sądów apelacyjnych kierują do: 1) Ministra Sprawiedliwości, jeżeli mają być wysłane do państwa, z którym jest zawarta umowa międzynarodowa przewidująca porozumiewanie się sądów za pośrednictwem organów centralnych, albo do państwa, z którym brak stosunków dyplomatycznych; 2) właściwych sądów lub innych organów państw, z którymi zawarto umowy międzynarodowe przewidujące bezpośrednie porozumiewanie się sądów lub jeżeli taki sposób porozumiewania się dopuszcza prawo państwa wezwanego; 3 ) przedstawicielstwa dyplomatycznego lub urzędu konsularnego Rzeczypospolitej Polskiej, w pozostałych przypadkach. Zwracając się do przedstawicielstw dyplomatycznych lub urzędów konsularnych Rzeczypospolitej Polskiej, sądów i innych organów państw obcych o udzielenie pomocy prawnej, sądy sporządzają m.in. wniosek o doręczenie pisma adresatowi przebywającemu za granicą i zwrócenie urzędowo poświadczonego potwierdzenia odbioru, załączając formularz potwierdzenia odbioru (§ 37 i $\S 42$ rozporządzenia). Sąd może przy tym zarządzić dokonanie doręczenia przez zwykłe oddanie pisma, jeżeli adresat zgodzi się dobrowolnie je przyjać; w formie przewidzianej przez prawo wewnętrzne państwa wezwanego, jeżeli sąd uzna, że pismo powinno być doręczone nawet $\mathrm{w}$ razie odmowy dobrowolnego przyjęcia go przez adresata; $w$ formie szczególnej, jeżeli forma ta nie jest sprzeczna $\mathrm{z}$ prawem państwa wezwanego (§ 38).

\subsection{Pelnomocnik do doręczeń}

Powyżej zostały przedstawione aktualnie przewidziane sposoby dokonywania doręczeń zagranicznych (oczywiście z wyjątkiem komunikacji elektronicznej). Można przy tym postawić tezę, iż to właśnie doręczenia dokonywane w jeden, a czasem kolejno stosowane, inne sposoby, posiadają najistotniejsze znaczenie, bowiem dla tzw. „nawiązania kontaktu” ze stroną kluczową kwestią jest skuteczność pierwszego doręczenia w sprawie. Za rzecz oczywistą uznać należy, iż jeśli w sprawie działa ustanowiony do prowadzenia sprawy pełnomocnik, to o ile on inicjuje to postępowanie, nie ma potrzeby dokonywania doręczeń dla strony (co do zasady). Pełnomocnikiem strony w postępowaniu administracyjnym może być osoba fizyczna posiadająca zdolność do czynności prawnych (art. 33 § 1 k.p.a.), natomiast $\mathrm{w}$ postępowaniu sądowo-administracyjnym podmioty enumeratywnie

${ }^{11}$ Rozporządzenie to zostało bowiem wydane w oparciu o upoważnienie ustawowe zawarte w art. $41 \S 2$ ustawy z dnia 27 lipca 2001 r. - Prawo o ustroju sądów powszechnych. 
wymienione $\mathrm{w}$ art. 35 p.p.s.a., m.in. adwokat lub radca prawny, a ponadto inny skarżący lub uczestnik postępowania, jak również małżonek, rodzeństwo, wstępni lub zstępni strony oraz osoby pozostające ze stroną w stosunku przysposobienia, a także inne osoby, jeżeli przewidują to przepisy szczególne. Ponadto stronę może reprezentować w postępowaniu przed sądami i innymi organami władzy publicznej także prawnik z Unii Europejskiej w oparciu o przepisy ustawy z 5 lipca 2002 r. o świadczeniu przez prawników zagranicznych pomocy prawnej w Rzeczypospolitej Polskiej. Prawnik z Unii Europejskiej ma przy tym obowiązek wskazać osobę upoważnioną do odbioru pism w Rzeczypospolitej Polskiej, którą może być także adwokat lub radca prawny, jeśli prawnik UE z nimi współdziała (art. 39 ust. 1 ustawy). W przypadku natomiast, gdy w postępowaniu z udziałem podmiotu mającego miejsce zamieszkania, pobytu zwykłego bądź siedzibę poza granicami kraju, nie działa pełnomocnik do prowadzenia sprawy, zaś jak wynika z wyżej przeprowadzonych rozważań, doręczenia zagraniczne są czasochłonne, ustawodawca przewidział obowiązek ustanowienia tzw. pełnomocnika do doręczeń mającego miejsce zamieszkania w kraju. Obowiązek ustanowienia takiego pełnomocnika w postępowaniu sądowo-administracyjnym spoczywa na podmiotach, które nie mają miejsca zamieszkania lub zwykłego pobytu albo siedziby w Rzeczypospolitej Polskiej lub innym państwie członkowskim Unii Europejskiej, Konfederacji Szwajcarskiej lub państwie członkowskim Europejskiego Porozumienia o Wolnym Handlu (EFTA) - stronie umowy o Europejskim Obszarze Gospodarczym i nie ustanowiły pełnomocnika do prowadzenia sprawy mającego miejsce zamieszkania lub siedzibę w Rzeczypospolitej Polskiej (art. 299 § 2 p.p.s.a.). Podobnie na gruncie postępowania administracyjnego strona, która nie ma miejsca zamieszkania lub zwykłego pobytu albo siedziby w Rzeczypospolitej Polskiej lub innym państwie członkowskim Unii Europejskiej, jeżeli nie ustanowiła pełnomocnika do prowadzenia sprawy zamieszkałego w Rzeczypospolitej Polskiej i nie działa za pośrednictwem konsula Rzeczypospolitej Polskiej, jest obowiązana wskazać w Rzeczypospolitej Polskiej pełnomocnika do doręczeń (art. $40 \S 4$ k.p.a.). Obowiązek taki nie dotyczy natomiast podmiotów z państw członkowskich Unii Europejskiej (bądź wymienionych w art. $299 \S 1$ p.p.s.a.). Wcześniej regulacje k.p.a. i p.p.s.a. nie przewidywały takiego rozróżnienia, lecz wymagały w każdym przypadku ustanowienia takiego pełnomocnika przez stronę zamieszkałą, przebywającą bądź mającą siedzibę za granica, pod rygorem odpowiednio: pozostawienia $\mathrm{w}$ aktach ze skutkiem doręczenia (art. $40 \S 5$ k.p.a. - w brzmieniu obowiązującym do dnia 1 listopada 2015 r.), odrzucenia skargi strony (art. $299 \S 2^{12} \mathrm{~W}$ zW. $\mathrm{z}$ art. $58 \S$ pkt 3 p.p.s.a. - w brzmieniu obowiązującym do dnia 22 września 2015 r.) bądź pozostawienia pisma uczestnika w postępowaniu sądowym w aktach sprawy ze skutkiem doręczenia (art. $299 \S 3^{13}$ p.p.s.a.

\footnotetext{
${ }^{12}$ Aktualnie art. 299 § 3 p.p.s.a.

${ }^{13}$ Aktualnie art. $299 \S 4$ p.p.s.a.
} 
- w brzmieniu obowiązującym do dnia 22 września 2015 r.). Zmiana przepisów w tym zakresie wynikała z zakwestionowania przez Trybunał Sprawiedliwości art. $1135^{5}$ k.p.c. stanowiącego odpowiednik tych przepisów w postępowaniu administracyjnym. Trybunał słusznie bowiem wskazał, iż „Artykuł 1 ust. 1 rozporządzenia nr 1393/2007 dotyczącego doręczania w państwach członkowskich dokumentów sądowych i pozasądowych w sprawach cywilnych i handlowych oraz uchylającego rozporządzenie nr 1348/2000 należy interpretować w ten sposób, że sprzeciwia się on uregulowaniu państwa członkowskiego, które przewiduje, że dokumenty sądowe przeznaczone dla strony, której miejsce zamieszkania lub zwykłego pobytu znajduje się w innym państwie członkowskim, są złożone do akt postępowania ze skutkiem doręczenia, gdy strona ta nie ustanowiła pełnomocnika do doręczeń" ${ }^{14}$. Zarówno zatem wymóg ustanowienia takiego pełnomocnika, jak i skutek braku jego wypełnienia (identyczne jak w poprzednio obowiązującym stanie prawnym) aktualnie obarcza jedynie podmioty spoza Unii Europejskiej, natomiast nie ma żadnych przeszkód, aby takiego pełnomocnika wskazał podmiot działający na obszarze jednego z państw członkowskich Unii Europejskiej. Nic nie stoi także na przeszkodzie, aby przy pierwszym, a nawet kolejnych doręczeniach kierowanych do takiego podmiotu informować go o prawie ustanowienia takiego pełnomocnika.

Z uwagi na ograniczone ramy niniejszego opracowania szczegółowe omówienie wymogów stawianych takim pełnomocnikom i sposobów ich wskazywania musi zostać pominięte. Podkreślić przy tym można, że w literaturze pozycja pełnomocnika do doręczeń została już szeroko omówiona zarówno w komentarzach do k.p.a. i p.p.s.a., jak i odrębnych opracowaniach (zob. np. Cieślak 2012, 9-19).

\section{WNIOSKI}

Podsumowując powyższe rozważania, skoncentrowane głównie na problematyce związanej z dokonywaniem doręczeń zagranicznych bezpośrednio stronie (uczestnikowi) postępowania, bez udziału pełnomocnika bądź pełnomocnika do doręczeń, stwierdzić należy, że w ogólnym postępowaniu administracyjnym brakuje jednolitego modelu doręczania pism. Niewątpliwie sposobem najprostszym i najszybszym jest doręczanie za pośrednictwem operatora pocztowego, jednak z wyżej przedstawionych rozważań wynika, że takie doręczenia są skuteczne w zasadzie jedynie w przypadku, gdy adresat odbierze pismo i pokwituje jego odbiór. W przypadku awizowania przesyłki, czy też braku pokwitowania jej odbioru, doręczenia nie można uznać za prawidłowe. Pozostałe sposoby doręczania z uwagi na ich ilość i różnorodzajowość ( $\mathrm{w}$ tym w zależności od przepisów, jak i praktyki państwa, na terenie którego ma nastapić doręczenie), niekiedy

${ }^{14}$ Wyrok TS z 19 grudnia 2012 r. w sprawie C-325/11 Adler v. Orłowscy, Dz. U. UE. L.2007. 
konkurencyjność, czy wreszcie konieczność rozróżnienia w zależności od przynależności państwa, w którym ma nastapić doręczenie, do danej organizacji międzynarodowej (Unii Europejskiej, Konfederacji Szwajcarskiej lub Europejskiego Porozumienia o Wolnym Handlu (EFTA) - strony umowy o Europejskim Obszarze Gospodarczym) powodują zarówno szereg problemów z ustaleniem zarówno sposobu, jak i podmiotu, za pomocą którego może nastapić doręczenie, pomijając czas trwania tych czynności. Brak unormowania instytucji doręczenia jest szczególnie niezrozumiały na gruncie prawodawstwa Unii Europejskiej. O ile bowiem w zakresie postępowania cywilnego doszło do przyjęcia aktu w zasadzie kompleksowo regulującego sposoby doręczeń i potwierdzania odbioru przesyłek oraz ich skutki (rozporządzenie nr 1393/2007), o tyle na gruncie postępowania administracyjnego zdecydowanie odczuwalny jest jego brak. Jak się wydaje, można byłoby przecież przyjąć regulację analogiczna, dokonać zmiany przywołanego rozporządzenia, rozszerzając zakres jego stosowania o sprawy administracyjne, bądź też nawet odsyłając do odpowiedniego stosowania. W odniesieniu do państw spoza obszaru Unii Europejskiej zastosowanie mogłaby znaleźć Konwencja Haska o doręczaniu za granicą dokumentów sądowych i pozasądowych w sprawach cywilnych lub handlowych, oczywiście pod warunkiem jej przyjęcia przez państwa-sygnatariuszy ${ }^{15}$.

Brak takiej regulacji dziwi również z uwagi na istnienie takiego odrębnego uregulowania tej problematyki w postępowaniu podatkowym. Zgodnie bowiem z treścią art. 154a ustawy z 29 sierpnia 1997 r. - Ordynacja podatkowa, organ podatkowy może wystapić do władzy państwa członkowskiego Unii Europejskiej właściwej w sprawach podatkowych, zwanej dalej „obcą władzą”, z wnioskiem o doręczenie pisma, gdy doręczenie za pośrednictwem operatora pocztowego osobie przebywającej na terytorium tego państwa nie jest możliwe lub gdy powodowałoby nieproporcjonalnie duże trudności ${ }^{16}$. Powyższe rozwiązanie przewidziane zostało na zasadach wzajemności (art. 154b Ordynacji podatkowej). Zastosowanie tego sposobu doręczenia ogranicza się co prawda tylko do państw Unii Europejskiej, ale biorąc pod uwagę, iż to właśnie na obszarze tych państw zamieszkuje, przebywa bądź ma siedzibę większość podmiotów, do których kierowana jest korespondencja zagraniczna, stanowi znaczące usprawnienie i przyspieszenie wymiany korespondencji. W zakresie doręczeń w sprawach podatkowych

${ }^{15} \mathrm{Na}$ marginesie można wskazać, iż w praktyce, $\mathrm{z}$ braku innych możliwości, można pokusić się o próbę doręczenia w oparciu o Konwencję Haską - z zapewnieniem wzajemnego zastosowania.

${ }^{16}$ Regulacja ta, w dacie jej uchwalania, stanowiła implementację nieobowiązującej już dyrektywy Rady 2004/56/WE z dnia 21 kwietnia 2004 r. zmieniającej dyrektywę 77/799/EWG dotyczącą wzajemnej pomocy właściwych władz Państw Członkowskich w obszarze podatków bezpośrednich, niektórych podatków konsumpcyjnych i podatków od premii ubezpieczeniowych (podaję za: Niezgódka-Medek 2015). Aktualnie natomiast obowiązuje Dyrektywa Rady 2011/16/ UE z dnia 15 lutego 2011 r. w sprawie współpracy administracyjnej w dziedzinie opodatkowania i uchylająca dyrektywę 77/799/EWG. 
obowiązuje także wielostronna umowa międzynarodowa - Konwencja o wzajemnej pomocy administracyjnej w sprawach podatkowych, sporządzona w Strasburgu 25 stycznia 1988 r. Stronami Konwencji jest 88 państw zarówno z Europy, jak i z innych kontynentów, np. Chiny, Australia, USA, Kanada, Izrael, Brazylia, Indie (http://www.coe.int/en/web/conventions/full-list/-/conventions/treaty/127/ signatures). Zdecydowanie natomiast brakuje tego rodzaju uregulowania międzynarodowego dla doręczeń w sprawach administracyjnych w ramach wzajemnej pomocy państw. Niewątpliwie coraz szerzej stosowane są doręczenia w ramach komunikacji elektronicznej, niemniej aby sposób ten można zastosować, adresat musi wyrazić na to zgodę, a ponadto sposób ten de facto może zostać zastosowany w sytuacji, gdy doszło już do pierwszego kontaktu z adresatem (bądź w oparciu o złożony przez niego wniosek, bądź po pierwszym doręczeniu).

Aktualnie trwają co prawda prace zmierzające do ujednolicenia procedury administracyjnej ze względu na znaczące różnice w państwach członkowskich UE, w celu stworzenia modelu kodeksu postępowania administracyjnego dla administracji UE, który może też służyć jako wzór kodeksu postępowania administracyjnego dla państw członkowskich, prowadzący do pewnej unifikacji rozwiązań prawnych z podniesieniem sprawności działania nowoczesnej administracji (Wierzbowski 2015, XXI). Prace nad modelem Kodeksu zbiegają się z pracami podjętymi przez Parlament Europejski nad stworzeniem jednolitej procedury dla administracji UE. Niemniej nawet jeśli akt taki zostanie przyjęty, to wiązać będzie jedynie administrację UE, zaś wprowadzenie rozwiązań wzorujących się na postanowieniach tego aktu nie spowoduje tym samym ułatwień w doręczaniu korespondencji, o ile nie zostanie wprowadzone w tych państwach na zasadach wzajemności.

Reasumując stwierdzić należy, że źródłem istotnych problemów praktycznych jest brak unormowań dotyczących doręczania pism w postępowaniu administracyjnym między państwami UE (z wyjątkiem spraw podatkowych i celnych, w odniesieniu do których obowiązują stosowne regulacje). Wskazany brak jest źródłem nieuzasadnionego zróżnicowania standardów w zakresie doręczeń w zależności od przedmiotu postępowania. Potrzeba precyzyjnego ich określenia wydaje się być nieodzowna, zważywszy z jednej strony na znaczenie instytucji doręczenia w postępowaniu administracyjnym, $z$ drugiej zaś na fakt prowadzenia przez polskie organy administracji publicznej postępowań, w których strony przebywają bądź mają siedzibę za granicą (przykładem mogą być tu chociażby sprawy z zakresu pomocy społecznej).

\section{BIBLIOGRAFIA}

Chróścielewski, Wojciech. 2016. „Przepisy porządkowe w postępowaniu administracyjnym i sądowo-administracyjnym - racjonalne odmienności czy nieuzasadnione zróżnicowanie rozwiązań prawnych?” Zeszyty Naukowe Sadownictwa Administracyjnego 2.

Cieślak, Łukasz. 2012. „Pełnomocnik do doręczeń w postępowaniu administracyjnym ogólnym”. Nowe Zeszyty Samorzadowe 6. 
Cisowska-Sakrajda, Ewa. 2010. „Doręczanie pism w postępowaniu administracyjnym ogólnym i podatkowym w obrocie zagranicznym". Administracja. Teoria-Dydaktyka-Praktyka 3.

Ciszewski, Jan. 2006. „Postępowanie w zakresie obrotu zagranicznego przed sądami administracyjnymi". Przeglad Sadowy 10.

Łaszczyca, Grzegorz, Andrzej Matan. 1998. Doręczenie w postępowaniu administracyjnym ogólnym i podatkowym. LEX/el.

Niezgódka-Medek, Małgorzata, [w:] Babiarz, Stefan, Bogusław Dauter, Bogusław Gruszczyński, Roman Hauser, Andrzej Kabat, Małgorzata Niezgódka-Medek. 2015. Ordynacja podatkowa. Komentarz. LEX/el.

Piłaszewicz, Marcin. 2014. „Wątpliwości wokół doręczania przesyłek w postępowaniu sądowo-administracyjnym w obrocie zagranicznym". Glosa 3.

Szuma, Jan, [w:] Sawczyn, Wojciech, Jan Szuma. 2014. Doręczenia w postępowaniu administracyjnym $i$ sqdowo-administracyjnym. Wrocław: Presscom.

Wach, Bartosz, [w:] Bogucki, Stanisław, Anna Krasuska-Terrillon, Barbara Mikołajczyk, Bartosz Wach, Marek Zieliński. 2015. Funkcje konsulów Rzeczypospolitej Polskiej. Komentarz. LEX/ el.

Wierzbowski, Marek [w:] Wierzbowski, Marek, Herwig C. H. Hofmann, Jens-Peter Schneider, Jacque Ziller. 2015. ReNEUAL Model kodeksu postępowania administracyjnego Unii Europejskiej. Warszawa: C.H. Beck.

\section{AKTY NORMATYWNE}

Dyrektywa Rady 2004/56/WE z dnia 21 kwietnia 2004 r. zmieniająca dyrektywę 77/799/EWG dotyczącą wzajemnej pomocy właściwych władz Państw Członkowskich w obszarze podatków bezpośrednich, niektórych podatków konsumpcyjnych i podatków od premii ubezpieczeniowych. Dz. Urz. UE L 127 z 29.04.2004: 70; Dz. Urz. UE. Polskie wydanie specjalne, rozdz. 9, t. 2: 13 .

Dyrektywa Rady 2011/16/UE z dnia 15 lutego 2011 r. w sprawie współpracy administracyjnej w dziedzinie opodatkowania i uchylająca dyrektywę 77/799/EWG. Dz. U. UE. L.2011.64.1.

Konwencja o doręczaniu za granicą dokumentów sądowych i pozasądowych w sprawach cywilnych lub handlowych sporządzona w Hadze dnia 15 listopada 1965 r. Dz. U. 2000, Nr 87, poz. 968.

Konwencja o stosunkach konsularnych sporządzona w Wiedniu dnia 24 kwietnia 1963 r. Dz. U. 1982, $\mathrm{Nr} 13$, poz. 98 .

Konwencja o ułatwieniu dostępu do wymiaru sprawiedliwości w stosunkach międzynarodowych sporządzona w Hadze w dniu 25 października 1980 r. Dz. U. 1995, Nr 18, poz. 86.

Konwencja o wzajemnej pomocy administracyjnej w sprawach podatkowych, sporządzona w Strasburgu dnia 25 stycznia 1988 r. Dz. U. 1998, Nr 141, poz. 913.

Regulamin Generalnego Światowego Związku Pocztowego wraz z załącznikiem - Regulaminem wewnętrznym Kongresów, Światowej Konwencji Pocztowej wraz z Protokołem końcowym, Porozumieniem dotyczącym pocztowych usług płatniczych, sporządzone w Dausze dnia 11 października 2012 r. Dz. U. 2015, poz. 1522.

Regulamin Poczty Listowej Światowego Związku Pocztowego sporządzony w Bernie dnia 28 stycznia 2005 r. Dz. U. 2007, Nr 108, poz. 744.

Rozporządzenie Ministra Sprawiedliwości z dnia 28 stycznia 2002 r. w sprawie szczegółowych czynności sądów w sprawach z zakresu międzynarodowego postępowania cywilnego oraz karnego w stosunkach międzynarodowych. Tekst jedn. Dz. U. 2014, poz. 1657.

Rozporządzenie nr 1393/2007 Parlamentu Europejskiego i Rady z dnia 13 listopada 2007 r. dotyczące doręczania w państwach członkowskich dokumentów sądowych i pozasądowych w sprawach cywilnych i handlowych (doręczanie dokumentów) oraz uchylające rozporządzenie Rady (WE) nr 1348/2000. Dz. U. L 324: 79. 
Umowa między Rzecząpospolitą Polską a Rumunią o pomocy prawnej i stosunkach prawnych w sprawach cywilnych sporządzona w Bukareszcie dnia 15 maja 1999 r. Dz. U. 2002, Nr 83, poz. 752.

Ustawa z dnia 14 czerwca 1960 r. - Kodeks postępowania administracyjnego. Tekst jedn. Dz. U. 2016, poz. 23 ze zm. (k.p.a.).

Ustawa z dnia 17 listopada 1964 r. - Kodeks postępowania cywilnego. Tekst jedn. Dz. U. 2004, poz. 101 ze zm. (k.p.c.)

Ustawa z dnia 18 lipca 2002 r. o świadczeniu usług drogą elektroniczną. Tekst jedn. Dz. U. 2013, poz. 1422 ze zm.

Ustawa z dnia 25 czerwca 2015 r. - Prawo konsularne. Dz. U. 2015, poz. 1274.

Ustawa z dnia 27 lipca 2001 r. - Prawo o ustroju sądów powszechnych. Tekst jedn. Dz. U. 2015, poz. $133 \mathrm{ze} \mathrm{zm}$.

Ustawa z dnia 29 sierpnia 1997 r. - Ordynacja podatkowa. Tekst jedn. Dz. U. 2015, poz. 613 ze zm.

Ustawa z dnia 30 sierpnia 2002 r. - Prawo o postępowaniu przed sądami administracyjnymi. Tekst jedn. Dz. U. 2016, poz. 718 ze zm. (p.p.s.a.)

Ustawa z dnia 5 lipca 2002 r. o świadczeniu przez prawników zagranicznych pomocy prawnej w Rzeczypospolitej Polskiej. Tekst jedn. Dz. U. 2014, poz. 134 ze zm.

\title{
Renata Lewicka
}

\section{SERVICE OF LETTERS ABROAD IN THE ADMINISTRATIVE AND COURT PROCEEDINGS}

\begin{abstract}
The issues connected with service of letters in the administrative and court proceedings beyond the Republic of Poland under the European Union law and particularly under the case law of the Court of Justice, establishing standards of the letter service become more and more important. The source of significant practical problems is the fact that there are no regulations concerning the service of letters in general administrative proceedings both between the EU states (with the exception of tax and customs issues which are regulated) and to the states which are not members of the European Union. Apart from a classic way of serving a letter upon somebody by a postal operator which is unfortunately not always effective, some other ways of service are applied in an auxiliary way. However, it must be noted that there are no regulations normalizing consistently methods of a letter service in various types of the proceedings which leads to unjustified diversity in standards in the range of serving letters depending on a subject matter of the proceedings.
\end{abstract}

Keywords: serving letters, serving letters abroad, foreign legal turnover, a service agent, diplomatic and consular law. 